\author{
Agnieszka KRAMEK ${ }^{1}$ \\ Justyna GUMIENIAK ${ }^{2}$
}

\title{
CZYNNIKI WPEYWAJĄCE NA OBNIŻENIE HAŁASU PRZEKŁADNI ZĘBATYCH
}

\begin{abstract}
Wibroaktywność pojawiająca się w trakcie pracy przekładni zębatych ma wiele źródeł pochodzenia. Kształtowanie warunków akustycznych jest możliwe jeszcze na etapie projektowania i konstruowania. Dodatkowo wysokie wymagania ekonomiczne i eksploatacyjne zmuszają do poszukiwania innowacyjnych metod badawczych w zakresie technik symulacyjnych. Przyczyny parametrycznych drgań przekładni zębatych mają podłoże wewnętrzne i zewnętrzne, które są najczęściej wymuszane przez oddziaływania innych zespołów roboczych maszyn i trudne do wyeliminowania. Najważniejszymi czynnikami wpływającymi na poziom hałasu podczas pracy kół zębatych są: rodzaj przekładni, profil zęba, podziałka - moduł, kąt przyłożenia, faza wzębiania i wyzębiania wynikająca $z$ położenia średnic tocznych na odcinku czynnym przyporu, zmiany profilu zęba, stopień pokrycia kół zębatych, luz międzyzębowy, obciążenie zęba, poziom jakości, wykończenie powierzchni (chropowatość), bicie i niewyważenie, przełożenie, rezonans, lepkość smaru oraz korpus przekładni.
\end{abstract}

Słowa kluczowe: wibroaktywność, przekładnie zębate

\section{Wprowadzenie}

Przekładnie zębate są powszechnie stosowane w układach napędowych maszyn, dlatego odgrywają ogromną rolę w kształtowaniu warunków akustycznych w miejscach pracy. Hałas powstający podczas eksploatacji różnych urządzeń mechanicznych generują w dużej mierze drgania parametryczne kół zębatych zależne od masy, sztywności i współczynnika tłumienia [1]. Na cichą pracę przekładni zębatych ma wpływ wiele czynników pojawiających się na różnych etapach projektowania i konstruowania, zanim powstaną koła zębate. Dopasowanie jednego lub więcej z nich, zanim przekładnia zostanie wykonana, często podnosi koszty, ale może spowodować znaczne obniżenie poziomu hałasu i wydłużenia czasu poprawnej pracy urządzenia [2]. Najlepszym momentem na rozwiązywanie problemów hałasu przekładni zębatych jest etap projektowania. Późniejsze

\footnotetext{
1 Autor do korespondencji: Agnieszka Kramek, Politechnika Rzeszowska im. Ignacego Łukasiewicza, Wydział Mechaniczno-Technologiczny w Stalowej Woli, ul. Kwiatkowskiego 4, 37-450 Stalowa Wola, e-mail: a.kramek@prz.edu.pl, ORCID: 0000-0002-5463-6771.

2 Justyna Gumieniak, Politechnika Rzeszowska im. Ignacego Łukasiewicza, Wydział Mechaniczno-Technologiczny w Stalowej Woli, ul. Kwiatkowskiego 4, 37-450 Stalowa Wola.
} 
poprawki są zwykle bardzo kosztowne i niesatysfakcjonujące. Należy jednak zawsze zachować równowagę pomiędzy potrzebą obniżenia hałasu a zadowalającą konstrukcją [3]. Coraz wyższe wymagania ekonomiczne, konstrukcyjne i eksploatacyjne stawiane projektantom powodują, że w rezultacie mają oni do rozwiązania skomplikowane zadania. Niezastąpionym narzędziem umożliwiającym uzyskanie postawionych założeń są techniki symulacyjne. Pozwalają one na wykorzystanie modeli przekładni zębatych znanych z literatury $[2,4]$.

Przyczyny parametrycznych drgań przekładni zębatych mają podłoże wewnętrzne i zewnętrzne, które są najczęściej wymuszane przez oddziaływania innych zespołów roboczych maszyn i trudne do wyeliminowania.

Tabela 1. Przyczyny drgań przekładni zębatych [1]

\begin{tabular}{|c|c|}
\hline \multicolumn{2}{|c|}{ Mechanizm wymuszeń dynamicznych } \\
\hline Wymuszenia zewnętrzne & Wymuszenia wewnętrzne \\
\hline - Zmiany obciążeń eksploatacyjnych & - Wahania sztywności zębów \\
\hline - Błędy montażowe systemu & $\begin{array}{l}\text { - Zmiany kierunku siły tarcia } \mathrm{w} \text { punkcie } \\
\text { tocznym przyporu }\end{array}$ \\
\hline - Niewyrównoważenie układu & - Błędy wykonawcze \\
\hline - Inne zewnętrzne wymuszenia dynamiczne & $\begin{array}{l}\text { - Błędy przy zazębianiu i wyzębianiu par } \\
\text { zębów }\end{array}$ \\
\hline & - Zmiany sztywności łożyskowania \\
\hline
\end{tabular}

Najważniejszymi czynnikami wpływającymi na poziom hałasu podczas pracy kół zębatych są: rodzaj przekładni, profil zęba, podziałka - moduł, kąt przyłożenia, faza wzębiania i wyzębiania wynikająca z położenia średnic tocznych na odcinku czynnym przyporu, zmiany profilu zęba, stopień pokrycia kół zębatych, luz międzyzębowy, obciążenie zęba, poziom jakości, wykończenie powierzchni, bicie i niewyważenie, przełożenie, rezonans, lepkość smaru oraz korpus przekładni. Do oceny stanu technicznego kół zębatych stosuje się diagnostykę wibroakustyczną, polegającą zazwyczaj na pomiarze amplitudy drgań korpusu i analizie częstotliwościowej sygnału drganiowego [5]. Badania prowadzone w różnych ośrodkach skupiają się na redukcji drgań u źródła, tj. w zazębieniu kół zębatych i łożyskach, a także na zmniejszeniu wibroaktywności obudów, np. poprzez zastosowanie dodatkowego wzmocnienia korpusu.

\section{Analiza czynników hałasotwórczych w pracy przekładni zębatych}

\section{Rodzaj przekładni}

Wśród wielu typów przekładni najbardziej cichobieżne są przekładnie walcowe (o zębach prostych, śrubowych i podwójnie śrubowych) o osiach równoległych. Przekładnie kątowe stożkowe o zębach prostych lub kołowo-łukowych są zazwyczaj znacznie głośniejsze - wynika to głównie z technologii ich wykonania 
i montażu. Przekładnie walcowe umożliwiają utrzymanie ścisłych tolerancji wykonania i zapewniają pracę przy minimalnym tarciu powierzchni współpracujących zębów, co sprawia, że pracują ciszej [6]. Przekładnia śrubowa ma dodatkową zaletę utrzymywania więcej niż jednego zęba w kontakcie podczas pracy (spiralny stopień pokrycia). $\mathrm{Z}$ tego powodu jest możliwa redukcja hałasu w porównaniu z kołami zębatymi walcowymi o zębach prostych [7]. W przekładniach o zębach podwójnie śrubowych (tzw. strzałkowych) główny problem polega na zapewnieniu położenia punktu przecięcia obu spirali śrubowych w jednej płaszczyźnie dla obu współpracujących kół. Wszelkie niewielkie odchylenia wykonawcze, w połączeniu z bezwładnością osiową tych kół zębatych znacznie utrudnią równy podział obciążeń i płynne działanie, są przyczyną wibracji i hałasu. Optymalnym rodzajem przekładni we wszystkich zakresach prędkości jest przekładnia śrubowa o pojedynczej linii śrubowej (lewej i prawej).

\section{Profil zęba}

Wiele lat temu opracowano inne profile zębowe niż ewolwentowe. Żaden z nich nie został szeroko zastosowany, głównie z powodu braku wystarczających zalet i tradycji produkcji uzasadniających ewentualne odstępstwo od zastosowania form ewolwentowych [6]. Przekładnie z zębami o profilu łukowym zatrzymują więcej smaru pomiędzy zazębiającymi się elementami, w rezultacie powoduje to redukcję hałasu i zużycia. Niemniej jednak są one wciąż w dużej mierze traktowane jako eksperymentalne i nie okazały się bardziej ciche niż typ ewolwentowy. Ponadto producenci posiadają zazwyczaj technologię do wytwarzania zarysów ewolwentowych, co jest jednym z głównych powodów, dla których nie rozpowszechniły się inne typy zarysów. Inne formy zarysów zębów są projektowane konkretnie do przenoszenia znacznie większych obciążeń niż równoważne zęby ewolwentowe i są przeważnie znacznie głośniejsze. Bogate doświadczenie z tradycyjnymi przekładniami ewolwentowymi doprowadziło do modyfikacji powierzchni zęba w celu cichszej pracy, czego nie udało się wypracować dla niestandardowych rozwiązań [8].

\section{Podziałka (moduł, m)}

Dla cichej i płynnej pracy należy wybrać możliwie najmniejszą podziałkę $(t=\pi \cdot m)$, dla danych warunków obciążenia. Im mniejsza jest podziałka, tym większa liczba zębów współpracuje jednocześnie - jest większy stopień pokrycia. Zapewnia to płynniejsze przenoszenie obciążenia, zmniejszając amplitudę drgań w strefie wzębiania i wyzębiania - spowoduje to cichszą pracę przekładni.

Im mniejsza będzie podziałka, tym mniejszy ząb i niższy wskaźnik wytrzymałości pracujących kół zębatych. Aby to zrekompensować, istnieje kilka możliwości: zwiększyć średnice podziałowe koła zębatego, szerokość wieńca lub użyć materiału o wyższej wytrzymałości. Takie koła zębate wymagają precyzyjnego szlifowania. W rezultacie potrzeba więcej czasu na wykonanie zębów, co zwiększa koszt przekładni [9]. 


\section{Kąt przyłożenia (przyporu)}

Tam, gdzie niski poziom hałasu jest kluczowym wymogiem, należy wybrać możliwie najmniejszy kąt przyłożenia. W związku ze stale rosnącym zapotrzebowaniem na przekładnie o większym obciążeniu, wielu projektantów skłaniało się ku kątowi przyłożenia $25^{\circ}$. Koła zębate o kącie przyłożenia $25^{\circ}$ rzeczywiście zapewniają większą wytrzymałość, ale są głośniejsze, ponieważ zmniejsza się znacznie stopień pokrycia. Kąt przyłożenia $20^{\circ}$ wydaje się być najlepszym kompromisem pomiędzy siłą a głośnością. Inne kąty przyporu można zastosować tam, gdzie jeden z tych czynników jest kluczowy - kąt $141^{\circ}{ }^{\circ}$ zapewnia mniejszy hałas, a kąt $25^{\circ}$ daje większą wytrzymałość. Reasumując, kąt przyłożenia $20^{\circ}$ jest dobrym kompromisem pomiędzy cichym działaniem i wysokim obciążeniem [6].

\section{Faza wyzębiania}

Przy współpracy (podczas obrotu) dwóch kół zębatych, gdzie jedno z nich jest kołem napędzającym, a drugie napędzanym, punkty styku zarysów obu zębów wyznaczają na linii przyporu odcinek zwany czynnym odcinkiem przyporu (length of contact LC). Linia przyporu przecina oś łączącą środki obu kół w punkcie zwanym punktem tocznym. Punkt ten jest punktem czynnego odcinka przyporu i dzieli go na dwie części: część formowaną w fazie wzębiania (approach action) i część tworzoną w fazie wyzębiania (recess action). Współpraca zarysów dwóch zębów jest kombinacją poślizgu i toczenia. Poślizg pojawia się na początku wzębiania, a jego wartość maleje do zera w punkcie tocznym. Przy wejściu w strefę wyzębiania pojawia się poślizg o przeciwnym kierunku, a jego wartość zwiększa się aż do chwili całkowitego wyzębienia. W momencie przechodzenia przez punkt toczny występuje zerwanie filmu olejowego, powodując zwiększone tarcie. Badania wykazały, że zjawiska zachodzące w strefie wzębiania są bardziej niebezpieczne niż $w$ strefie wyzębiania i powodują zatarcia i większy hałas. Stąd sugestia - aby zmniejszyć hałas, należałoby zwiększyć strefę wyzębiania. Możliwe są różne kombinacje, włącznie z wersją, że czynny odcinek przyporu jest strefą wyzębiania. Należy jednak pamiętać, że w takim przypadku pracującą częścią zęba jednego koła jest tylko głowa (powyżej średnicy tocznej), a drugiego koła stopa (poniżej średnicy tocznej). Wielkości poślizgu mogą więc być tak duże, że spowodują znaczne zacieranie i niszczenie zębów jednego z kół (rys. 1.) [8].
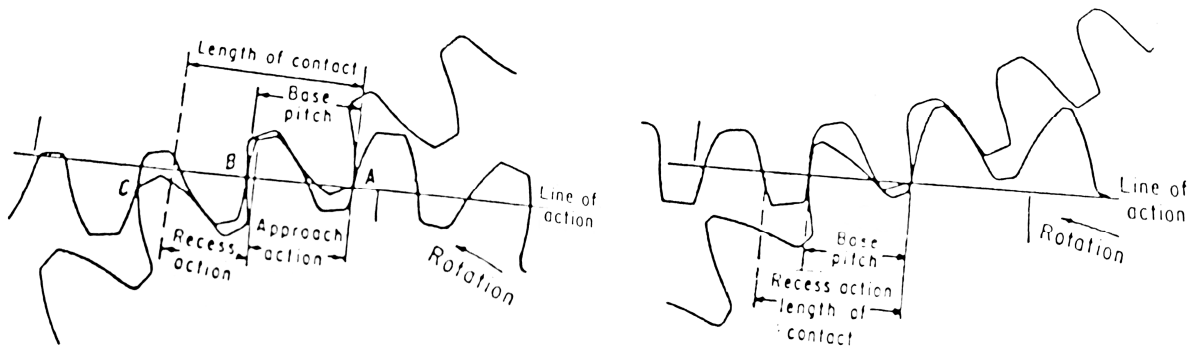

Rys. 1. Fazy wzębiania i wyzębiania [8] 


\section{Zmiany profilu zęba}

Właściwa modyfikacja zębów jest bardzo ważna, jeśli przekładnia ma być cicha i wytrzymała. Badania dynamiczne wykazały, że większość przekładni o dużej mocy, a także wiele lekko obciążonych wymaga modyfikacji profilu zęba. Zapewnia to płynne przesuwanie się zębów, będących w kontakcie i tych bez kontaktu, bez uderzania, a także kompensuje niewspółosiowość, błędy w produkcji i ugięcia pod obciążeniem [5]. Ważne jest odciążenie głowy i stopy zęba. Modyfikacja polega na delikatnym pocienianiu głowy zęba po obu stronach stopniowo od pewnej wysokości do wierzchołka i podcięciu stopy zęba po obu stronach. W niektórych przypadkach nawet efekt hydrodynamiczny oleju smarowego może powodować, że zęby emitują stukot podczas pracy, nawet jeśli nie ma fizycznego kontaktu na końcówce zęba lub w jej pobliżu.

Beczkowanie linii zęba to kolejna niezwykle ważna modyfikacja zęba. Ugięcia wałów wynikające z obciążenia i niewielkie błędy w wykonaniu otworów łożyskowych w korpusie mogą powodować twardy kontakt $\mathrm{z}$ bocznymi końcami zęba. Dlatego pożądane jest modyfikowanie linii zęba koła zębatego - na kształt beczki - w celu wyśrodkowania obszaru styku (rys. 2.). Wraz ze wzrostem obciążenia następuje płynne „rozciąganie” styku do momentu obciążenia całej powierzchni bocznej.

Rys. 2. Modyfikacje profilu zęba [8]
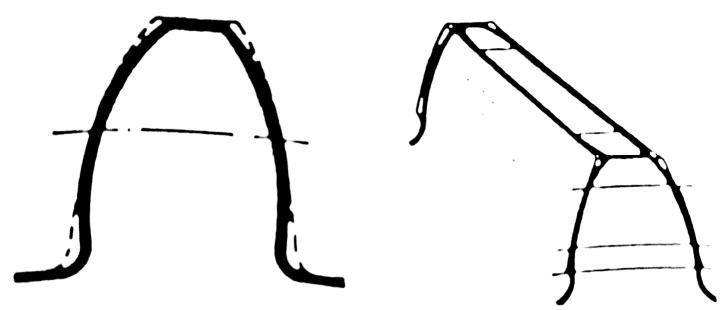

Z badań wynika, że poprawę właściwości akustycznych przekładni zębatych można uzyskać, stosując uzębienie wysokie charakteryzujące się wartością czołowego wskaźnika zazębienia (stopnia pokrycia) ok. 2,0 [1, 5].

\section{Stopień pokrycia zazębiania}

Hałas przekładni podczas pracy można zmniejszyć, projektując ją tak, aby stopień pokrycia był liczbą całkowitą. Testy pokazują, że jeśli stopień pokrycia wynosi 2,0, to dokładnie dwa zęby są zawsze w kontakcie i uzyskuje się płynniejsze przenoszenie obciążenia. Stopień pokrycia zazębiania $(\varepsilon)$ oznacza średnią liczbę zębów w bezpośrednim kontakcie - w przypadku kół zębatych walcowych o zębach prostych współczynnik ten uzyskuje się, dzieląc długość odcinka przyporu (length of contact $L C$ ) przez podziałkę zasadniczą (base pitch $P_{b}$ ) - rys. 1 .

W przypadku przekładni śrubowych całkowity stopień pokrycia jest sumą pokrycia czołowego i śrubowego. Jako przykład można założyć, że para kół zębatych ma współczynnik pokrycia wynoszący 1,5 . Na początku dwie pary zębów 
będą w kontakcie, dopóki nie zostanie osiągnięty punkt, w którym wiodąca para ulega rozłączeniu. W tym momencie tylko druga para będzie w kontakcie do czasu, aż kolejna para zębów się połączy. Dlatego w pewnym momencie dwa zęby stykają się, dzieląc obciążenie, a w innym punkcie tylko jeden ząb. Powoduje to oscylację ugięcia zęba, która, choć niewielka, przyczynia się do generowania dźwięku (rys. 3.).

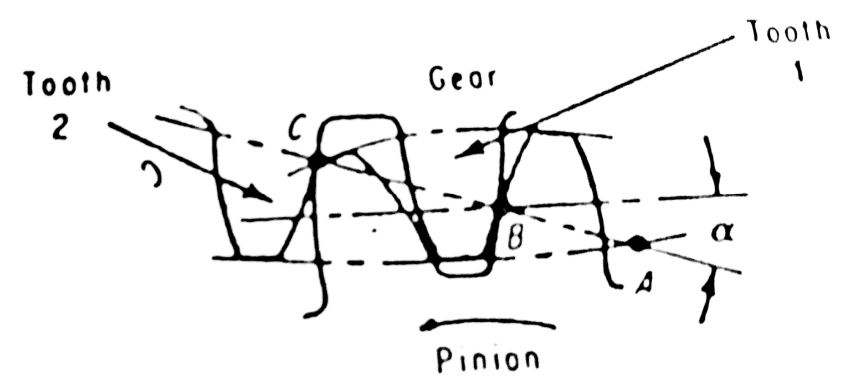

Rys. 3. Współpraca zębów przy współczynniku pokrycia 1,5 [8]

Przy wyższym współczynniku pokrycia więcej zębów styka się przy przenoszeniu obciążenia, co zapewnia większą efektywność. Praktycznie dla redukcji hałasu i obciążeń dynamicznych najlepszy jest współczynnik o wartości 2,0. Znacznie łatwiej zrealizować to kryterium dla zębów skośnych, gdzie zwiększoną wartość wskaźnika zazębiania uzyskuje się przez dobranie odpowiedniej wartości kąta pochylenia linii zęba. W przypadku zębów prostych uzyskanie takiego stopnia pokrycia zazębiania nie jest już takie łatwe [5].

\section{Luz międzyzębowy}

Odkształcenia termiczne, ugięcia wszelkich elementów podczas pracy, obciążenia odśrodkowe, drgania skrętne wałów oraz błędy wykonania uzębień szczególnie błędy podziałek i wynikające stąd bicia uzębień - wymagają, aby podczas wzębiania i wyzębiania zachować odpowiedni luz międzyzębowy. Zbyt mały luz może być powodem nadmiernego hałasu. Jednakże w napędach pracujących w układzie przód-tył, w których utrata ruchu i uderzenia podczas pracy może stanowić problem, stosuje się mniejsze luzy.

\section{Obciążenie zęba}

Wraz ze wzrostem obciążenia zębów obserwuje się zmniejszony poziom hałasu. Wszystkie elementy przekładni - koła zębate, wały, korpus i inne - są wykonane zawsze z pewnymi błędami, które stanowią o niedoskonałości i powodują hałas. Jeżeli przekładnia (jej elementy) zostanie poddana większym obciążeniom, wówczas zwiększone ugięcia dominują nad błędami wykonawczymi i poprawiają równomierność przenoszenia mocy - przez to zmniejszają hałas przekładni. Wpływ zużycia i awarii na obciążenia dynamiczne działające na koła zębate 
przedstawiono w pracy [10]. Odpowiedni dobór parametrów konstrukcyjnych umożliwia redukcję nadwyżek sił dynamicznych w zazębieniach i łożyskach oraz przyczynia się do obniżenia wartości skutecznych amplitud drgań poprzecznych w łożyskach [4]. Nieskomplikowana zmiana geometrii kół zębatych zastosowanych w przekładniach pozwala czasem na obniżenie poziomu zjawisk wibroaktywności i nie zawsze wiąże się to z dużymi nakładami finansowymi [2].

\section{Poziom jakości}

Jednym z łatwiejszych sposobów zmniejszania hałasu jest podniesienie poziomu jakości wykonania kół zębatych. Przy wyższej jakości (przy mniejszych błędach podziałki) obciążenia dynamiczne są mniejsze, co obniża poziom hałasu. Podniesienie wymagań jakościowych kół zębatych zwiększa jednak znacznie koszty produkcji. Wiąże się to z koniecznością zastosowania nowoczesnych obrabiarek oraz technik i technologii do wykańczania (szlifowania) uzębień. Szacuje się, że podniesienie poziomu jakości uzębień o cztery klasy zwiększa koszty o ok. $25-50 \%$ [9].

\section{Wykończenie powierzchni}

Chropowatość powierzchni zębów w powiązaniu z modyfikacją zarysu i linii zęba ma bardzo istotny wpływ na głośność przekładni. Im mniejsza jest chropowatość powierzchni, tym lepsza praca. Technologią stosowaną do obróbki wykończającej powierzchni zębów przed obróbka cieplną jest wiórkowanie. Metoda ta wygładza tylko powierzchnię. Kształt ewolwenty zależy od zachowania warunku parzystości styków wejścia-wyjścia układu wiórkownik-koło. Wszelkie deformacje powstałe w wyniku obróbki termicznej pozostają - co jest dużą wadą stosowania tej metody. Szlifowanie natomiast stosuje się po obróbce cieplnej i po tej technologii uzyskuje się wyższą jakość uzębienia poprzez zmniejszenie błędów podziałki międzyzębowej i całkowitej [8].

\section{Bicie i niewyważenie}

Każdy niewyważony element wirujący - a koło zębate może być wykonane również z biciem - wywołuje siłę odśrodkową, która wprowadza nierównomierność pracy zazębień. To zjawisko jest szczególnie ważne w przekładniach szybkoobrotowych, dlatego kontrolowanie stanu niewyważenia jest bardzo istotne.

\section{Przełożenie}

Aby zapobiec cyklicznemu kontaktowi zęba koła z tymi samymi zębami na kole współpracującym, należy przyjąć wartość przełożenia, która nie jest liczbą całkowitą. Stała współpraca tych samych zębów jest powodem zwiększonego hałasu. Jeżeli doda się jeden ząb do któregoś z elementów, wówczas wydłuży się czas, kiedy znów spotkają się te same zęby - zmniejszy się częstość drgań, a tym samym hałas [9]. 


\section{Rezonans}

Wszelkie elementy rezonujące przekładni, czyli elementy poddane działaniu różnych obciążeń, są powodem wibracji i hałasu. Zjawisko to dotyczy szczególnie obracających się części, a więc wałów i osadzonych na nich kół zębatych. Jeżeli częstość drgań wymuszonych - pochodzących od prędkości roboczych osiągnie wartość częstości drgań własnych układu, wówczas nastąpi zjawisko rezonansu, czyli ogromnej wibracji i tym samym dużego hałasu. Należy bezwzględnie unikać takich sytuacji. Zaleca się tak dobierać prędkości robocze, aby omijać krytyczne częstości drgań własnych. Różnica pomiędzy nimi powinna wynosić co najmniej $20 \%$.

Obciążenia elementów obrotowych są przenoszone również na korpus przekładni i inne elementy nośne. Właściwa konstrukcja obudów może znacznie się przyczynić do zablokowania emisji dźwięku do otoczenia. Na ogół żeliwny korpus jest cichszy niż stalowy, ale ten jest z kolei bardziej wytrzymały. W celu poprawy tłumienia obudowy stalowej należy unikać cienkich, płaskich płyt, należy stosować usztywniacze, żebra wzmacniające lub dodatkowy materiał - częstość drgań własnych zależy od masy elementu, im większa masa, tym mniejsza jest częstość drgań własnych. Jeżeli konieczne jest dalsze tłumienie hałasu, można umieścić pomiędzy dwiema stalowymi płytami warstwę materiału syntetycznego, takiego jak filc, kauczuk syntetyczny lub polimer, tworząc w ten sposób dodatkową wzmocnioną warstwę materiału tłumiącego [9].

$\mathrm{Z}$ przeprowadzonej analizy modalnej i wyznaczenia rozkładu amplitudy normalnej drgań na powierzchni korpusu wynika, że znaczącym czynnikiem obniżającym wibroaktywność przekładni jest odpowiednie usytuowanie użebrowania górnej płyty korpusu, pozwalające na obniżenie drgań [11, 12].

$\mathrm{W}$ procesie projektowania jest możliwe wybranie częstotliwości zazębienia (indukcji drgań) poprzez zmianę liczby zębów kół zębatych, a także częstotliwości własnych obudowy poprzez zastosowanie żeber w taki sposób, aby częstotliwości te były jak najdalej od siebie [7]. Aby ograniczyć przenoszenie hałasu przez podłogę, obudowę należy zamontować na materiale izolującym wibracje, umieszczonym bezpośrednio pod przekładnią. Do wytłumienia powstałych drgań należy zastosować stosunkowo sztywną laminowaną gumę lub inny rodzaj materiału o podobnych właściwościach.

\section{Lepkość smaru}

Im wyższa lepkość smaru kół zębatych, tym większe działanie tłumiące współpracujących kół zębatych. Wyższe lepkości powodują pewną utratę sprawności i mocy, jednak oprócz tłumienia drgań obniżają znacznie zatarcia zębów, a tym samym zużywanie przekładni [6].

\section{Podsumowanie}

Analiza wibroaktywności podczas pracy przekładni zębatych jest przedmiotem badań wielu specjalistów. Problem jest bardzo złożony, zależny od szeregu 
czynników związanych zarówno z cechami konstrukcyjnymi, jak i sposobem eksploatacji urządzenia. Obniżenie poziomu hałasu i drgań wymaga wnikliwych badań, które często łączą tradycyjną laboratoryjną analizę stanowiskową z technikami symulacyjnymi. Modelowanie komputerowe umożliwia tworzenie potencjalnych rozwiązań i znacznie skraca czas analizy, jednak w dużej mierze opiera się na założeniach obiektów rzeczywistych i ostatecznie optymalizacja konstrukcji wymaga empirycznego potwierdzenia wyniku w laboratorium.

\section{Literatura}

[1] Wieczorek A., Metody zmniejszania hałasu przekładni zębatych - zmiana wskaźnika zazębienia, Bezpieczeństwo Pracy, 11(2008), s. 9-11.

[2] Peruń G., Kształtowanie wibroaktywności przekładni zębatej wspomagane badaniami laboratoryjnymi oraz symulacyjnymi, Logistyka 4(2015), s. 801-808.

[3] Rogula J., Metody obniżania poziomu hałasu napędu w tokarkach, Zeszyty Naukowe Politechniki Śląskiej, 83(2014), s. 205-212.

[4] Peruń G., Wpływ wybranych czynników konstrukcyjnych i eksploatacyjnych na wibroaktywność przekładni zębatej, Zeszyty Naukowe Politechniki Śląskiej, 77(2012), s. 61-68.

[5] Wieczorek A., Konstrukcyjne metody zmniejszania drgań mechanicznych przekładni zębatych, Bezpieczeństwo Pracy, 07-08(2009), s. 34-37.

[6] Ochęduszko K., Koła zębate, WNT, Warszawa 1969.

[7] Figlus T., Wilk A., Madej H., Łazarz B., Investigation of gearbox vibroactivity with the use of vibration and acoustic pressure start-up characteristics, The Archive of Mechanical Engineering, 2(2011), s. 209-222.

[8] Bradley W.A., How to design noise out of gears, Machine Design, December 13, Philadelphia Gear Corp. 1973, s. 149-153.

[9] Drago R.J., How to design quiet transmissions, Machine Design, December 11, 1980, s. 175-181.

[10] Bartelmus W., Zimroz R., Vibration condition monitoring of planetary gearbox under varying external load, Mechanical Systems and Signal Processing, 23(2009), s. 246-257.

[11] Wilk A., Madej H., Figlus T., Analiza możliwości obniżenia wibroaktywności korpusu przekładni zębatej, Eksploatacja i Niezawodność, 2(2011), s. 42-49.

[12] Folęga P., Madej H., Wilk A., Wpływ modyfikacji korpusu przekładni zębatej na jej wibroaktywność, Przegląd Mechaniczny, 6(2009), s. 33-37. 
